\title{
Penerapan Yurisdiksi Alien Tort Claim Act Dalam Perspektif Hukum Pidana Internasional
}

\section{Sefriani}

\section{Abstrak}

ATCA restricts its jurisdiction by imposing some doctrines such as minimum contact, forum non-convenience, political question, international commity and act of state doctrine. Besides that, it also ignores the international criminal law principles such as presumption of innocence, expeditious trial, equity of arms and the atendance of the suspect in the court. The existence of par im parem in habet imperium principle recognized in international law causes the decision of American Court is meaningless.

\section{Pendahuluan}

Yurisdiksi atau kewenangan mengadili yang dimiliki pengadilan suatu negara merupakan manifestasi dari kedaulatan yang dimiliki oleh negara tersebut. Kedaulatan negara dalam hukum internasional dibatasi oleh hukum internasional dan kedaulatan negara lain. Dengan demikian suatu negara tidak dapat melaksanakan yurisdiksinya bilamana hal tersebut bertentangan dengan hukum internasional. Suatu negara juga tidak dapat melaksanakan yurisdiksinya bilamana hal tersebut melanggar kedaulatan negara lain.

Yurisdiksi universal dimana semua negara memiliki yurisdiksi terhadap pelaku kejahatan intemasional sudah lama dikenal dalam hukum internasional. Dengan demikian semua negara meskipun tidak memiliki keterkaitan sama sekali dengan kewarganegaraan pelaku maupun korban juga tempat dilakukannya kejahatan dapat memproses secara hukum pelakunya. Beberapa negara seperti Belgia dan Inggris sudah memiliki undang-undang nasional penerapan yurisdiksi universal ini. Keberadaan yurisdiksi universal dimaksudkan supaya pelaku kejahatan internaisonal tidak lolos dari penghukuman dimanapun ia berada. Kejahatan internasional seperti kejahatan perang, piracy, kejahatan kemanusiaan juga genocide dianggap kejahatan terhadap seluruh umat manusia.

Amat disayangkan sampai saat ini perhatian hukum intemasional pada kejahatan universal masih lebih besar pada diri si pelaku. Bahwa pelaku tidak dapat bersembunyi di balik tugas negara, bahwa pelaku jangan sampai lolos dari hukuman, namun demikian sedikit sekali perhatian terhadap hak-hak korban.

Berkaitan dengan yurisdiksi dan hak-hak korban ini, pada tahun 1980 masyarakat internasional dikejutkan oleh suatu putusan pengadilan negara bagian New York, Amerika Serikat dalam kasus Filartiga $\vee$ Pena Irala Berdasarkan ketentuan nasional Amerika, yang 
terkenal dengan sebutan Alien Tort Claim Act (ATCA), Pengadilan New York menyatakan memiliki yurisdiksi atas gugatan perdata yang diajukan oleh keluarga Filartiga terhadap PenaIrala seorang polisi Paraguay yang telah menculik, menyiksa dan membunuh Juanito Filartiga (WN Paraguay) di Paraguay pada tanggal 29 Maret 1976. Juanito Filartiga di siksa sampai meninggal karena aktifitas politik ayahnya, Dr Joel Filartiga yang dipandang mengancam stabilitas politik Paraguay. Di samping membunuh Juanito Filartiga, tentara Paraguay dibawah komando Pena Irala telah menangkap dan mengancam membunuh pengacara keluarga Filartiga. Mereka juga melakukan teror setiap malam di sekitar rumah Filartiga, serta memenjarakan ibu dan saudara perempuan Juanito Filartiga. Ketika mengetahui Pena Irala berada di Amerika Serikat, saudara perempuan Juanito Filartiga yang lain bernama Doly dan ayahnya mengajukan gugatan secara perdata ke Pengadilan Amerika atas perbuatan melawan hukum (tort) yang dilakukan Pena Irala. Gugatan keluarga Filartiga berhasil, pengadilan memutuskan keluarga Filartiga berhak mendapatkan ganti rugi sebesar $\$ 10,4$ million. ${ }^{1}$ Dalam kasus Filartiga ini hakim menyatakan memiliki yurisdiksi di bawah ATCA karena penggugat adalah orang asing dan tindakan yang dilakukan tergugat, menyiksa sampai mati Juanito Filartiga adalah melanggar the law of Nations atau hukum internasional. ${ }^{2}$

Keberhasilan gugatan Filartiga diPengadilan Amerika mendorong diajukannya kasus-kasus serupa ke Pengadilan Amerika. Mantan pemimpin Serbia Bosnia, Rodovan Kardzik, Mantan Presiden Philipina Ferdinand Marcos, juga mantan menteri pertahanan dan keamanan Guatemala pernah diajukan sebagai tergugat di pengadilan-pengadilan Amerika Serikat, digugat berdasarkan ATCA. ${ }^{3}$ Dalam kasus Marcos, hakim menetapkan para penggugat berhak atas $\$ 770$ million compensatory damages, dan $\$ 1,2$ billion punitive damages. ${ }^{4}$ Dalam kasus Kadzik V Karadzik 1995 misalnya Pengadilan Federal Manhattan memerintahkan Rodovan Karadzik, mantan pemimpin Serbia-Bosnia itu membayar ganti rugi sebesar $\$ 4,1$ billion kepada penggugat yang mengatasnamakan warga muslim Croatia atas kejahatan perkosaan, pembunuhan, penyiksaan yang dilakukan tentara Serbia Bosnia di bawah komando Rodovan Karadzik saat konflik Balkan. ${ }^{5}$ Kasus lain, pada bulan Oktober 1994, Sintong Panjaitan, seorang jendral Indonesia yang bertugas di Timor Timur, dihukum membayar ganti rugi sebesar

1 "Plain Responses to Attacts on The Alien Tort Claims Act (ATCA)", Department of Policy and Business Practices, Intemational Chamber of Commerce, December 2002, http//wwwiccwbo.org, hlm.2, diakses Pebruari 2005

2ATCAmenetapkan sebagai berikut: The US District Court shall have original jurisdiction of any civil action by an alien for a tort only, committed in violation of the law of nations or a treaty of the United States

"William Glaberrson, "US Court become arbiters of Global :Rights and Wrongs", dalam harian New York Times, 21 Juni 2001

${ }^{4} J e n n i f e r$ Green and Beth Stephens, "An Activist Guide: Bringing International Human Rights Claims in United States Courts", Center forConstitutional Rights, www.ccrny.org/v2/ilegal/dues/activist\%20guide.pdf,akses 2 Maret 2005, him. 8

${ }^{5} \mathrm{lbid}$ 
\$1,4. pada Helen Todd, ibu dari Kamal Ahmed Bamadhaj, seorang mahasiswa Australia yang tewas di tangan tentara Indonesia saat insiden Santa Cruez 1991. ${ }^{6}$

Ada beberapa hal yang menarik untuk dikaji dari penerapan yurisdiksi berdasarkan ATCA oleh pengadilan-pengadilan di Amerika. Pertama, sebagaimana kasus-kasus yang dipaparkan sebelumnya, sebenamya Amerika tidak memiliki keterkaitan sama sekali dengan kasus-kasus tersebut, baik terhadap kewarganegaraan pelaku, korban juga tempat dilakukannya kejahatan yang dituduhkan. Kedua, mayoritas perkara yang diajukan penggugat adalah perkara mengenai kejahatan-kejahatan yang sangat serius dalam hukum internasional, seperti genocide, crimes against humanity, war crime, torture, dan lain-lain. Ketiga, meskipun perkara yang diajukan menyangkut perkara pidana internasional tetapi proses persidangannya dilakukan secara perdata. Putusan pengadilan tidak memberikan sanksi badan pada pihak yang dituduh melakukan kejahatan-kejahatan internasional tersebut (tergugat) melainkan hanya memberikan ganti rugi pada si korban (penggugat). Apa yang dipraktikkan pengadilanpengadilan Amerika ini berdasarkan ATCA, mengadili secara perdata terhadap kasus-kasus pidana internasional tidal dikenal sebelumnya bahkan dikatakan sebagai suatu anomali dalam praktik masyarakat internasional. Beberapa negara yang menerapkan yurisdiksi universal terhadap perkara-perkara pidana internasional memprosesnya secara pidana, bukan perdata.
Putusan Pengadilan-pengadilan Amerika dalam kasus-kasus sebagaimana dipaparkan sebelumnya banyak mendapat sorotan. Di satu sisi oleh para pendukung hak asasi manusia (HAM), pengadilan Amerika Serikat ini mendapat banyak pujian karena mendukung penegakan aturan-aturan HAM. Korban atau keluarganya hampir dipastikan tidak akan mendapatkan keadilan di pengadilan negaranya sendiri, mengingat pada umumnya pelaku adalah aparat negara, apa yang dilakukannya adalah atas perintah negara. Namun demikian di sisi lain, praktik yang dilakukan pengadilan Amerika menimbulkan kekhawatiran pada berbagai pihak. Pengadilan di Amerika dikatakan menjadi global police juga global attomey. Pengadilan di Amerika dikatakan juga memiliki tangan yang sangat panjang, dapat mengadili kasus-kasus yang sama sekali tidak berkaitan dengan Amerika. Apa yang dilakukan pengadilanpengadilan di Amerika berdasarkan ATCA tersebut juga dikatakan melanggar kedaulatan negara lain yang seharusnya memiliki yurisdiksi untuk menyelesaikan kasus tersebut ${ }^{7}$ ATCA dikatakan juga memungkinkan Amerika Serikat untuk melaksanakan yurisdiksi ekstrateritorial yang sangat berpotensi memaksakan nilai-nilai Amerika pada negara lain. Diargumentasikan juga bahwa ATCA merupakan bentuk imperialisme modern dan pelanggaran kedaulatan negara dimana perbuatan-perbuatan itu terjadi. ${ }^{8}$ Perwakilan perusahaan transnasional dan Bush Adminis-

${ }^{6} /$ bid, lihat juga Plain Responses to attack on the alien tort claim act (ATCA), op.cit, him. 12

${ }^{7}$ bid

${ }^{8} T$. Niles, "The very long arm of American Law", dalam Financial Times, 5 November 2002, juga D Griswold, "Abuse of $18^{\text {th }}$ century law threatens U.S Economic and Security Interest, 5 Januari 2003, tersedia di http/hww.cato.org/dailys/01-25-03.html, diakses 2 Maret 2005 
tration dalam kritiknya terhadap ATCA mengemukakan bahwa ATCA merupakan ancaman kebangkrutan ekonomi dunia dan merupakan pelanggaran yang serius terhadap hubungan luar negeri. ${ }^{9}$

Kritik yang lain lagi terhadap ATCA adalah bahwa penerapan hukum Amerika terhadap pihak lain adalah unfair karena mereka tidak mengetahui sama sekali tentang hukum Amerika dan juga bahwa perbuatan dilakukan di negara lain, sehingga seharusnya home country berdasarkan prinsip yurisdiksi teritoriallah yang berhak mengadili berdasarkan Hukum internasional bukanlah Amerika. ${ }^{10}$ Dalam kasus The Alvarez-Machaine" misalnya negara-negara Eropa yang tergabung dalam European Commission memprotes penerapan ATCA terhadap warga/perusahaan-perusahaan Eropa untuk tindakan yang dilakukan di luar wilayah Amerika Serikat. Komisi berharap adanya pengamanan terhadap hak-hak subjek hukum Eropa di bawah hukum internasional publik. ${ }^{12}$ Lebih lanjut dikemukakan oleh komisi bahwa seharusnya pengadilan Amerika memperhatikan local remedies rule serta sifat komplementer dari yurisdiksi universal. ${ }^{13}$

Terlepas dari kritik-kritik yang diajukan berbagai pihak sebagaimana dipaparkan di atas, tulisan berikut ini bermaksud untuk . mengkaji bagaimana penerapan yurisdiksi ATCA oleh pengadilan-pengadilan Amerika -dalam perspektif hukum pidana internasional.

\section{Ruang lingkup Penerapan Yurisdiksi- ATCA}

Kurang jelasnya ATCA menjadikan pengadilan Amerika Serikat banyak melakukan interpretasi sendiri terhadap yurisdiksi ATCA. Dari berbagai putusan atas kasus-kasus yang diajukan ke pengadilan Amerika Serikat menggunakan ATCA, analisis ruang lingkup penerapan ATCA dapat dikelompokkan menjadi beberapa hal. Pertama, menyangkut personal jurisdiction, kedua, menyangkut subject matter, dan ketiga menyangkut alasanalasan yang digunakan hakim untuk menolak perkara yang diajukan di bawah ATCA

\section{Personal jurisdiction under ATCA}

Dalam praktik penerapan ATCA hakim melakukan pembatasan ruang lingkup ATCA personal jurisdiction under ATCA, pertama, siapa yang dapat mengajukan gugatan (applicant), dan yang kedua, siapa yang dapat digugat (defendant). Yang dapat menjadi penggugat (applicant) berdasarkan ATCA

9"The Alien Claims Act UnderAttact", remark by Beth Stephen, dalam American Societ of International Law, Proceedings of Annual Meeting, Washington, 2004, hlm.54

10 "Plain Responses to Attacts on The Alien Tort Claims Act (ATCA)",op.cit., him. 6

"Dalam kasus iniAlvarez-Machain seorang dokter WN Mexico telah diculik dan dibawa ke Amerika oleh WN Mexico lainnya atas perintah Pemerintah Amerika karenaAlvarez diduga terlibat pembunuhan seorang polisi Mexico, agen DEA. Alvarez menuntut ganti rugi karena telah mengalami kidnapping, arbitrary detention, torture, cruel, inhuman and degrading treatmnet or punishmnet yang dialaminya ketika ia dipiundahkan secara paksa dari mexico ke Amerika., kasus selengkapnya lihat dalam US Engage "The Alen Tort Provision Corecting the Abuse of an Early Federalist Statute", op.cit., him. 3

${ }^{12}$ The European Commission's Amicus Curiae Brief in The Alvarez-Machain Case, hlm. 1-2

13/bid., hlm.4 
adalah sebagai berikut:14

1. korban (victim) sebagai penggugat (applicant/plaintiff) haruslah alien (orang asing) atau bukan warga Amerika Serikat (non US Citizen).

2. Gugatan/kasus harus diajukan atas nama korban atau keluarga dekatnya (close family member) seperti orang tua, anak, saudara kandung, dan suami atau istri korban atau kuasa hukum si korban.

Adapun yang dapat diajukan sebagai tergugat adalah sebagai berikut: ${ }^{15}$

1. Tergugat dapat individu, aparat negara, kelompok militer (paramilitery), organisasi

- atau juga perusahaan. ${ }^{16}$

2. Tergugat tidak harus warga atau berkebangsaan Amerika Serikat.

3. Tergugat harus secara fisik hadir di Amerika Serikat, tinggal di Amerika Serikat, ada di Amerika Serikat, atau memiliki aset di Amerika Serikat .

4. Tergugat bukanlah orang yang menikmati kekebalan diplomatik berdasarkan Konvensi Diplomatik. Bila tergugat adalah pejabat diplomatik yang sedang bertugas di Amerika ia menikmati kekebalan diplomatik dan dilindungi dari segala tuntutan hukum.

5. Untuk efektifnya gugatan harus diyakini tergugat memiliki rekening atau aset lain di Amerika .
6. Keterlibatan tergugat terhadap kasus yang diajukan dapat berupa keterlibatan langsung secara fisik, yaitu melaksanakan sendiri secara fisik pelanggaran hukum internasional yang dituduhkan. Sebagai contoh pejabat Ethiopia Kelbassa Negewo yang dituduh melakukan penyiksaan terhadap wanita di penjara Ethiopia.

7. Keterlibatan dapat juga berupa memberi perintah atau yang memiliki tanggung jawab pengawasan. Masuk kategori ini adalah seseorang yang mengetahui atau seharusnya tahu terjadinya pelanggaran dan gagal mencegah atau menghukum pelaku. Sebagai contoh adalah dalam kasus Radovan Karadzik, mantan pemimpin sipil Serbia Bosnia selama Bosnian Genocide, Hector Gramajo mantan Menteri Pertahanan Guatemala, Prosper Avril, mantan diktator Haiti dan Ferdinand Marcos mantan Presiden Philipina. Keempat mantan pemimpin ini seharusnya bertanggung. jawab atas perencanaan dan pelaksanaan pelanggaran HAM di wilayah kekuasaannya.

8. Gugatan terhadap pemerintah asing hanya mungkin dilakukan apabila pemerintah tersebut termasuk daftar negara sponsor terorism seperti Cuba, Iran, Irak, Korea Utara, Libya, Sudan dan Syria.

9. Gugatan terhadap perusahaan dapat

\footnotetext{
${ }^{14}$ Jennifer Green and Beth Stephens, op.cit., him. 3

${ }^{15}$ Alex Phelan, "The Alien Tort Claims Act: Successes and Limitations", Bhopal, Tuesday, January 24, -2006, umw.ringo.bard.edulhrp/projects/bhopal/phplib/student-list.php?, hlm.7-15, lihat juga Jennifer Green and Beth Stephens, op.cit, hlm 5-11 serta "Corporate Liability for Violations of international Human Rights Law," Dalam Harvard Law Review, 114 Harv. L. Rev. 2025, May, 2001, hlm5-9

${ }^{16} \mathrm{Gugatan}$ terhadap non state actor hanya dapat dilakukan untuk jenis kejahatan piracy, slave trading, genocide dan war crime. Hal ini nampak dalam keputusan pengadilan dalam kasus Kadzik-Karadzik , "Corporate Liability for Violations of International Human Rights Law," ibid., hlm.8
} 
Sefriani. Penerapan Yurisdiksi Alien Tort Claim Act ...

dilakukan jika perusahaan tersebut berkantor pusat di Amerika, atau melaksanakan kegiatan operasionalnya di Amerika untuk tuduhan keterlibatan pelanggaran HAM di Iuar wilayah Amerika.

\section{Subject Matter}

ATCA diterapkan terhadap pelanggaran the law of nations. Sayang sekali, pembentuk ATCA tidak mendefinisikan apa yang dimaksud dengan the law of nations ketika menetapkan ATCA. Kasus pertama penafsiran the:law of nations adalah ketika pengadilan dihadapkan pada pertanyaan apakah piracy merupakan pelanggaran the law of nations atau-bukan. Menjawab pertanyaan ini pengadilan dalam kasus United States v. Smith, 18 U.S. 153,1601 (1820) menyatakan bahwa: ${ }^{17} \cdot \ldots .{ }^{2}$

"IW]hat the law of nations on this subject is, may be ascertained by consulting 'the works of jurists; writing professedly on public law; or by the general usage and practice of nations; or by judicial decisions recognizing and enforcing that law.".

Selanjutnya pengadilan menyatakan juga bahwa ...that nearly all writers on the law of nations and maritime law concurred with the common law, which considered piracy: a violation of international law. .... Relying on these outsidesources, the Court held that piracy was a violation of international law.

Dalam kasus The Paquette Habana. 175 U.S. 677 (1900), Pengadilan menyatakan bahwa:

"International law is part of our law, and must be ascertained and administered by the courts of justice of appropriate jurisdiction as often as questions of right depending upon it are duly presented for their determination. For this purpose, where there is no treaty and no controlling executive or legislative actor judicial decision, resort must be had to the customs and usages of civilized nations, and...to the works of jurists and commentators who by years of labor, research, and experience have made themselves peculiarly well acquainted with the subjects of which they treat. Such works are resorted to by judicial tribunals, not for the speculation of their authors concerning what the law ought to be, but for trustworthy evidence of what the law really is."

Demikianlah dari dua kasus klasik di atas, Smith and Paquette Habana pengadilan menetapkan bahwa subject matter jurisdiction under the ATCA may be determined by referencing outside legal sources, common law and the laws of foreign nations.

Suatu putusan yang dianggap lebih modern, yaitu putusan tahun 1980 kasus Filartiga, dengan mengutip putusan hakim sebelumnya dalam kasus Smith dan Paquette Habana, hakim menyatakan bahwa: ${ }^{18}$

a. the law of nations is part of federal common law, and thus cases arising under the law of nations arise under the laws of the United States as required by Article III of the Constitution.

b. the law of nations "may be ascertained by consulting the works of jurists, writing professedly on public law; or by the general

${ }^{17}$ Chartes Charles F. Hollis, "Perpetual Mistrial: The Impropriety of Transnational Human Rights Litigation in United States Courts "http://www.scu.edu/scjil/archive/v1_HollisArticle, akses 6 Juni 2005, hlm. 18

${ }^{18} \mathrm{bid}$ 
usage and practice of nations; or by judicial decisions recognizing and enforcing that law.

c. a norm must "command "the general assent of civilized nations"' to be part of the law of nations.

d. the law of nations must be interpreted "not as it was in 1789, but as it has evolved and exists among the nations of the world today.

Dari hasil-hasil sebelumnya, yang dapat dikatakan sebagai pelanggaran terhadap the law of nations dan karenanya masuk dalam yurisdiksi ATCA adalah sebagai berikut: ${ }^{19}$

\section{a. Crimes Against Humanity, Including Murder, Rape, Mutilation and Torture ${ }^{20}$}

Jenis pelanggaran ini nampak antara lain dalam kasus Doe I v. Islamic Salvation Front, 993 F. Supp. 3 (D.D.C. 1998) juga Kadic, 70 F.3d 232, Trajano v.Marcos, 978 F.2d 493, 499 (9th Cir. 1992). Abbe-Jira v. Negewo. Abbe-Jira v. Negewo Kasus yang pertama adalah kasus kekerasan di Algeria setelah kemerdekaannya dari Perancis. Warga sipil sebagian besar wanita dan anak-anak dibunuh, diperkosa, butchered, dismembered, bumed and tortured. Penggugat menyatakan bahwa the Islamic Salvation Front bertanggung jawab di bawah ATCA atas kejahatan-kejahatan yang dilakukannya sebagaimana disebutkan di atas. ATCA tidak membedakan antara state actor dan non state actor untuk jenis-jenis pelanggaran hukum internaisonal tertentu. Pengadilan menetapkan bahwa apa yang dilakukan tergugat merupakan crimes against humanity sehingga masuk dalam yurisdiksi ATCA. Termasuk kategori crimes against humanity juga menurut pengadilan adalah rape, forced prostitution, forced impregnation, torture and summary execution.

\section{b. Cruel, Inhuman or Degrading Treatment and Disappearance ${ }^{21}$}

Dalam kasus Xuncax v. Gramajo, $886 \mathrm{~F}$. Supp. 162 (D. Mass. 1995), yang diajukan oleh 9 WN Guatemala, pengadilan pengadilan menyatakan bahwa:

that acts which "had the intent and the effect of grossly humiliating and debasing the plaintiffs, forcing them to act against their will and conscience, inciting fear and anguish, breaking physical or moral resistance, and/or forcing them to leave their homes and country and flee into exile" could be considered cruel, inhuman or degrading treatment.

Lebih lanjut pengadilan menyatakan bahwa semua yang dilakukan tergugat merupakan prohibited treatment, pelanggaran terhadap hukum internasional dan karenanya masuk dalam yurisdiksi ATCA. Ditambahkan pula oleh pengadilan bahwa "disappearance" had beenrenounced with "universal condemnation and opprobrium." Therefore, disappearance is a violation of the law of nations under the ATCA.

${ }^{19}$ Alex Phelan, "The Alien Tort Claims Act: Successes and Limitations", op.cit., him.14, lihat juga Jennifer Green and Beth Stephens, op.cit., hlm 9 serta "Corporate Liability for Violations of International Human Rights Law," op.cit., hlm.9

${ }^{20}$ Tom McNamara, op.cit., hlm 12

${ }^{21}$ bid 
Sefriani. Penerapan Yurisdiksi Alien Tort Claim Act ...

\section{c. Genocide G2 $^{22}$}

Genocide jelas dinyatakan sebagai pelanggaran hukum internasional menurut ATCA. Hal ini nampak antara lain dalam kasus Kadic, 70 F.3d 232; Termasuk dalam genocide antara lain:

(a) Killing members of the group;

(b) Causing serious bodily or mental harm to members of the group;

(c) Deliberately inflicting on the group conditions of life calculated to bring about its physical destruction in whole or in part;

(d) Imposing measures intended to prevent births within the group;

(e) Forcibly transferring children of the group to another group."

\section{d. Slavery and Forced Labor ${ }^{23}$}

Slavery dan forced labor dimasukkan dalam yurisdiksi ATCA nampak dalam kasus Kadic, Xuncax, 886 F. Supp. at 185, juga Iwanowa v. Ford Motor Co., Dalam kasus terakhir penggugat adalah warga Russia yang diculik dari rumahnya dan dibawa ke Jerman dan dibeli oleh tergugat. Tergugat memperkerjakan paksa penggugat di pabrik truk militer selama puluhan tahun sampai akhirnya dibebaskan oleh tentara sekutu. Penggugat menuntut ganti rugi di bawah ATCA untuk reasonable value of her service restitution for unjust enrichment ages for pain and suffering caused by inhuman working conditions.

Dalam kasus ini pengadilan menyatakan: that while the ATCA does not define the law of nations, a definition "may be ascertained" from the "works of jurists, writing professedly on public law; orby the general usage and practice of nations; or by " judicial decision recognizing and enforcing that law."

Dengan mengutip putusan Nuremberg Tribunals, pengadilan menetapkan bahwa forced labor merupakan pelanggaran "customary international law" di bawah ATCA.

Adapun beberapa perkara yang ditolak oleh pengadilan Amerika dengan alasan bukan merupakan pelanggaran terhadap hukum internasional dan karenanya tidak masuk yurisdiksi ATCA antara lain adalah kasus-kasus yang berkaitan dengan Airline Crashes, Constructive Expulsion, EnvironmentalAbuses and Cultural Genocide, Fraud, Breach of Fiduciary Duty and Misappropriation, Looting, Price Fixing juga Purchase of lllegally Seized Property.

Dari paparan di atas dapat disimpulkan bahwa standar the law of nations menurut pengadilan Amerika adalah definable, universal and obligatory (rather than hortatory) atau memiliki karakter jus cogens. Dalam kasus Xuncax v. Gramajo, 886 F. Supp. 162, 184 (D. Mass. 1995), Pengadilan menetapkan bahwa yurisdiksi ATCA mensyaratkan hal-hal sebagai berikut:24,

1. no state condone the act inquestion and there is a recognizable "universal" consensus of prohibition against it;

2. there are sufficient criteria to determine whether a given action amounts to the prohibited act and thus violates the norm;

2rlbid., hilm.13

${ }^{23} /$ bid

${ }^{24}$ TikkunaA.S.Gottschalk, "The Real Politil of Empire, dalam Joumal of Transnational Law and Policy, Vol $13 / \mathrm{l}, 2005, \mathrm{hlm} .283$ 
3. the prohibition against it is non-derogable and therefore binding at all times upon all actors.

Selanjutnya dapat disimpulkan pula bahwa mayoritas kasus ATCA yang berhasil adalah menyangkut perkara pelanggaran berat HAM (gross violances of human right) seperti torture yang dilakukan oleh aparat negara. Disamping torture pengadilan juga mengakui summary execution, genocide, war crimes, disappearance, prolonged arbitrary detention -slave labor, and cruel, inhuman or degrading punishement ada di bawah yurisdiski ATCA. Sebaliknya pengadilan menolak untuk mengakui perkara-perkara seperti nasionalisasi (property expropriation), support of armed forces and labor right of picketing. cultural genocide, environmental abuses abridgement of freedom of speech,price fixing, ordinary torts such as libel, fraud, breach of fiduciary duty, and misappropriation of funds. cultural genocide and environmental abuses ${ }^{25}$ sebagai pelanggaran hukum internasional. ${ }^{26}$

Tidak semua gugatan mendasarkan ATCA berhasil dengan kompensasi bagi penggugat. Dari pengamatan kegagalan kasus-kasus ATCA menurut hakim adalah karena alasan-alasan berikut:

\section{a. Tidak terpenuhinya syarat minimum contact doctrine}

Doktrin ini menghendaki adanya minimum contact tergugat dengan negara forum Menurut Jan Wouters, Leen De Smet \& Cedrick Ryngaert, yang dimaksud minimum contact adalah presence or continuos and systematic business dengan Amerika Serikat. Kehadiran polisi-Paraguay, Marcos, juga Kardzik di Amerika Serikat misainya memenuhi syarat kontak mimimum. Sebaliknya bentuk perusahaan transnasional yang sepenuhnya merupakan anak perusahaan (total subsisiary) dalam kasus keterlibatan perusahaan transnasional di Mynamar tidak memenuhi syarat minimum contact. Doktrin ini membuktikan bahwa ATCA tidak menganut prinsip universal absolut seperti halnya yang dianut oleh Belgia. ${ }^{27}$

\section{b. Forum non Convinience doctrine}

Berdasarkan doktrin ini, bilamana pengadilan mengidentifikasi adanya pengadilan atau forum alternatif yang dipandang lebih tepat atau memiliki keterkaitan (more closely link) terhadap kasus yang diajukan maka pengadilan dapat menolak (dismiss) perkara yang diajukan.

\section{c. Non justiciability doctrine or politic questions}

Berdasarkan doktrin ini, tergugat dapat meminta pengadilan untuk menolak perkara karena perkara yang diajukan bukan perkara hukum melainkan perkara politik atau merupakan masalah-masalah politik (politic questions) dan melanggar batas wilayah foreign policy. Doktrin ini mencakup masalah $\mathrm{In}$ ternational Comity dan Political Question.

\footnotetext{
${ }^{25}$ "Corporate Liability for Violations of International Human Rights Law," op.cit., hlm.6

${ }^{26}$ /bid., him.7

${ }^{27}$ Jan Wouters, Leen De Smet \& Cedrick Ryngaert, op.cit., him 7
} 
Sefriani. Penerapan Yurisdiksi Alien Tort Claim Act ...

\section{d. The Foreign Sovereignty Act and the Act of State Doctrine}

Pengadilan akan menolak perkara yang mempermasalahkan legalitas tindakan negara asing. Doktrin ini berasal dari prinsip dalam hukum kebiasaan internasional dimana negara asing memiliki imunitas di pengadilan nasional. Kritik terhadap doktrin ini adalah bahwa doktrin ini dipandang tidak konsisten dengan pengertian the law of nations yang diberikan oleh pengadilan. Seharusnya dengan pengertian yang diberikan bahwa hanya tindakan-tindakan yang memenuhi syarat specific, universal dan obligatory atau dengan kata lain masuk kategeri jus cogens maka seharusnya tidak ada perkecualian terhadap tergugat. Sanksi terhadap pelanggaran jus cogens seharusnya dapat diterapkan pada siapapun termasuk juga pada negara atau pihak yang memiliki kedaulatan. ${ }^{28}$

\section{Penerapan ATCA dalam Perspektif Hukum Pidana Internasional}

Hukum intemasional tidak membatasi suatu negara dalam menerapkan prescriptive jurisdictionnya, karena hal itu menyangkut urusan domestik yang merupakan kedaulatan suatu negara. Dengan demikian adalah sah-sah saja berdasarkan-hukum internasional tindakan Pemerintah Amerika Serikat mengeluarkan ATCA dalam rangka pelaksanaan prescriptive jurisdiction-nya.

Yurisdiksi universal dalam hukum internasional digunakan untuk yurisdiksi pidana sehingga sanksi terhadap pelaku bisa berupa hukuman badan berupa kurungan. Meskipun demikian tidak berarti bahwa korban tidak dapat menuntut ganti rugi-(reparation). Setelah pengadilan menetapkan terdakwa bersalah maka pengadilan atas permintaan korban atau atas inisiatif-pengadilan sendiri dapat menetapkan ganti rugi (reparation) bagi korban. Bilamana kasus tersebut diadili oleh pengadilan internasional maka pengadilan akan menyerahkan putusan tersebut untuk ditindaklanjuti di pengadilan nasional negara asal pelaku. Adapun dalam ATCA tidak dikenal sanksi badan atau pemenjaraan atau hukuman mati. ATCA hanya memberikan hak ganti rugi pada tergugat. Dalam kasus-kasus tertentu, ATCA memungkinkan penggugat (Plaintiff) mengajukan tuntutan kompensasi dan punitive damages sekaligus. Putusan US District Court New York 2002 dalam kasus Adel Chiminya Tochiana et al v Robert Gabriel Mugabe, Zimmbabwe African Union Patriotic Front (ZANU-PF), hakim menghukum tergugat membayar sebesar $71.250 .453 \$$, terdiri dari 20.250 .453 compensation damages dan $51.000 .000 \$$ punitive damagse..$^{29}$ Punitive damages hanya dikenal dalam sistem hukum nasional Amerika saja.

International Crime merupakan jenis-jenis kejahatan yang dianggap pelanggaran yang paling serius dalam hukum intemasional. Pelakunya dianggap sebagai enemy of all of nations, enemy all of mankind. Meskipun pelaku dianggap sebagai musuh seluruh umat manusia namun ia tetap harus mendapatkan hak-haknya yaitu diadili dalam proses peradilan yang adil (fair). Untuk tercapainya atau terwujudnya peradilan yang fair harus memenuhi prinsip-

28/bid., hlm. 129

${ }^{29}$ Jan Wouters, Leen De Smet \& Cedrick Ryngaert, op.cit., hlm.8 
prinsip umum yang dikenal dalam proses peradilan pidana intemasional yaitu :

\section{Prinsip Praduga Tak Bersalah (The Presumption of innocent)}

Hampir Semua sistem hukum pidana nasional negara-negara mengenal dan menerapkan prinsip bahwa seorang terdakwa harus dianggap tidak bersalah sampai kejahatannya terbukti. Pasal 21(3) ICTY, Pasal 20(3) ICTR serta Pasal 66 ICC secara tegas mengatur mengenai prinsp ini.

Menurut Cassese secara umum prinsip presumption of innocence mengandung halhal sebagai berikut: -

1. tersangka di dalam maupun di luar proses peradilan harus dianggap tidak bersalah sampai terbukti kejahatannya.

2. beban pembuktian di tangan penuntut (prosecutor), terdakwa dapat mengajukan bantahan atas bukti-bukti tersebut tanpa harus membuktikan ketidakbersalahannya.

3. Dalam menemukan kesalahan terdakwa, pengadilan harus yakin, tidak ragu sedikitpun akan tuduhan-tuduhannya dengan standar pembuktian tertentu. ${ }^{30}$

\section{Prinsip hakim yang bebas dan tidak} memihak (The principle that judges must be independent and impartial)

\section{Prinsip Peradilan yang cepat dan adil (fair and expeditious Trial principle)}

Proses peradilan yang fair merupakan hak terdakwa yang diakui dalam berbagai instrumen internasional seperti Pasal 9, 10 and 11 Universal Declaration of Human Rights, Pasal 9, 14 and 15 ICCPR, The UN Standard Minimum Rules for the Treatment of Prisoners, the UN Body of Principles for the Protection of All Persons under Any Form of Detention or Imprisonment (1988), Pasal 7 dan 15 Convention against Torture, the UN Basic Principles on the Independence of the Judiciary, the UN Guidelines on the Role of the Prosecutors, Pasal 26 The European Convention on Human right juga American Convention on $\mathrm{Hu}$ man right, serta the UN Basic Principles on the Role of Lawyers. Hak ini juga diakui dalam Pasal 67 Rome Statute of the International Criminal Court, Pasal 21(2) Statuta International Military Tribunal, Pasal 9 Interntational Military Tribunal for Far East, Pasal 21(2) Statuta ICTY, Pasal 20(2) Statuta ICTR, the Statutes and Rules of Procedure and Evidence of the Yugoslavia and Rwanda Tribunals, serta Geneva Conventions dan Protokolprotokolnya. Sedemikian luasnya pengaturan proses peradilan yang fair ini diatur dalam hukum internasional menjadikan Cassese tanpa ragu menyimpulkan bahwa proses peradilan yang adil dan cepat tidak hanya mendapatkan status sebagai hukum kebiasaan internasional tetaapi juga sebagai norma yang fundamental yang tidak dapat dikurangi atau diubah melalui perjanjian internasional (jus cogens). ${ }^{31}$

Prinsip peradilan yang adil dan cepat diwujudkan dalam 3 standar utama yaitu:

${ }^{30}$ Dalam sistem common law terkenal dengan L'intime conviction du judge (the judge's innermost conviction) adapun dalam sistem civil law terdapat istilah menetapkan kesalahan terdakwa tanpa keraguan sedikitpun. (finding the accused guilt beyond a reasanable doubf)

${ }^{31}$ Antonio Cassese, op.cit., hlm. 395 
a. Prinsip keseimbangan (equality of arms).

Konsekuensi dari prinsip keseimbangan adalah sebagai berikut;

1. terdakwa berhak mengetahui sepenuhnya faktor-faktor yang menjadikan dia sebagai terdakwa.

2. Terdakwa berhak menguji bukti-bukti yang diajukan penuntut. Proses peradilan harus memberikan jaminan kesempatan sejauh mungkin untuk pembelaan. Dalam pembelaannya terdakwa berhak menginspeksi semua buku, dokumen, foto dan bukti-bukti lain yang diajukan jaksa penuntut.

3. Terdakwa berhak menunjuk satu atau lebih pembela (defence counsel) bahkan jika perlu atas biaya pengadilan.

4. Terdakwa berhak memanggil saksi dan menguji silang (cross examine) setiap saksi yang diajukan jaksa. Terdakwa juga berhak mengajukan dihadirkannya saksi yang menguntungkan dirinya. Terdakwa juga berhak meminta pengadilan memberikan jaminan perlindungan pada saksi yang mungkin takut adanya ancaman kebebasannya dengan cara misalnya, pengambilan sumpah melalui video conference bilamana para saksi karena alasan tertentu menolak untuk hadir dalam proses persidangan.

\section{b. Publikasi proses persidangan}

Publikasi proses persidangan jelas merupakan cara yang baik untuk menjamin bahwa proses peradilan dilakukan berada di bawah pengamatan yang cermat publik, dilakukan dengan adil, dan bahwa hak terdakwa tidak dilanggar oleh sikap pengadilan yang memihak. Meskipun prinsip ini tidak ditemukan secara eksplisit dalam IMT maupun IMTFE tapi dapat ditemukan antara lain dalam Pasal 21 (2) Statuta ICTY, Pasal 20 (2) Statuta ICTR, Pasal 67 (1) Statuta ICC, Pasal 14 (1) ICCPR, Pasal 6 (1) European Convention on Human Right, juga Pasal 8 (5) American Convention on Human Right.

\section{c. Prinsip proses persidangan yang cepat (expeditioustrial)}

\section{Prinsip harus hadirnya terdakwa dalam proses persidangan (the principle that the accused must be - present at his trial)}

Syarat kehadiran terdakwa dalam persidangan pengadilan pidana internasional juga diakui sangatlah penting. European Court of Human Right dalam Poitrimol v France:

It is of capital importance that a defendant shuld appear, both because of his right to a hearing and because of the need to verify the accuracy of his statetements and compare them with those of the victim whose interest need to be protected and of the witnesses.

Selanjutnya, Pasal 63 (1) Statuta Roma 1998 tentang ICC dengan jelas mensyaratkan kehadiran terdakwa sebagai syarat mendasar (basic requirement)dimulainya persidangan.

Syarat kehadiran terdakwa dalam proses persidangan sangatlah penting demi terwujudnya peradilan yang adil. Dasar pemikiran pentingnya kehadiran terdakwa menurut Cassese adalah karena sifat peradilan pidana internasional yang kompleks. Dalam proses persidangan pengadilan internasional pengumpuian bukti-bukti terkadang sangatlah 
sulit karena faktor-faktor berikut: ${ }^{32}$.

1. as a rule the court is headquartered in a country far away from the place of the crime.

2. witnesses may be scattered over many countries.

3. there is no investigating judge charged with collecting evidence on behalf of both prosecution and defence; under the accusatorial system each party must search for and find the necessary evidence.

4. the lack of an international body of investigators under the control of the prosecutor endowed with the power of freely going wherever the evidence may happen to be to question witnesses and collect material evidence, makes investigations undertaken for the purpose of supporting or dismissing charges extremely complex, the same holds true for the defence, which may not count on the court's power to order investigators to collect evidence on the defence' behalf.

5. in most cases matters are further complicated by the fact that the crime which the accused is chaerged have been perpetrated years before the court proceedings start...

Sebagaimana karakteristik peradilan pidana internasional yang dipaparkan di atas maka untuk terciptanya peradilan yang adil kehadiran terdakwa sangatlah penting dalam persidangan. Bilamana ia hadir, pertama ia dapat dapat mengeluarkan instruksi pada pembelanya atau berkonsultasi dengan mereka atas bukti-bukti yang dapat dikumpulkan untuk méndukung kasusnya, sebaliknya bila ia tidak
- hadir dalam persidangan bahkan sekalipun ia diwakili oleh seorang pembela yang ditunjuk pengadilan tidak akan menghilangkan terjadinya proses peradilan yang salah (mistrial) atau ketidakadilan (miscamiage of justice). Hal ini dikarenakan dalam sebagian besar kasus pembela tidak memiliki kemampuan untuk mengumpulkan semua bukti penting untuk menyanggah tuduhan jaksa penuntut. Kedua, kehadiran terdakwa penting untuk uji silang (cross examination) saksi-saksi dari pihak jaksa penuntut. Tanpa kehadirannya terdakwa sulit melepaskan stigma yang menempel padanya sebagai pelaku kejahatan internasional, musuh seluruh umat manusia, yang umumnya dipublikasi di berbagai media massa. Ketiga, terdakwa dapat membuktikan hal-hal penting yang sangat dibutuhkan pengadilan dalam mengambil putusan karena ia dapat memutuskan untuk diambil sumpah dan dalam banyak kasus sikap dan penampilannya seringkali dapat menjadi hal-hal yang relevan untuk pengadilan memutuskan apakah ia bersalah atau tidak. Dengan demikian tidak berlebihan kiranya bila Cassese menyimpulkan bahwa terciptanya peradilan yang adil (fair) hanya akan terwujud dengan kehadiran terdakwa dalam proses persidangan.

Meskipun sangatlah penting kehadiran terdakwa di persidangan sebagaimana dipaparkan di atas namun harus diakui bahwa sampai saat ini tidak ada ketentuan yang dengan tegas melarang peradilan in absentia dalam hukum internasional. ${ }^{33}$ Dalam praktik, meskipun bisa memahami alasan diijinkannya pelaksanaan yurisdiksi universal

\footnotetext{
- '32/bid.; him. 403 .

' ${ }^{33}$ Pašal 14 (3) (d) ICCPR dan Pasal 6 (1) Eưropean Convention on Human Rights, yang relevan dikaitkan dengan proses peradilan diinterpretasikan tidak melarang peradilan in absentia.
} 
in absentia, European Court of Human Right mengemukakan bahwa negara-negara tersebut tetap harus melakukan hal-hal berikut:

1. terdakwa secara formal harus diberitahu tuduhan yang dikenakan padanya.

2. harus bisa dibuktikan bahwa terdakwa sengaja melarikan diri dari proses persidangan.

3. terdakwa berhak hadir dipersidangan setiap saat dan minta proses persidangan dimulai lagi, bahkan jika ia sudah dijatuhi hukuman dengan kata lain ia berhak atas putusan yang baru setelah pengadilan mendengarnya di persidangan.

4. terdakwa harus diakui haknya untuk dibela di pengadilan oleh pengacaranya (counse). Sumber hukum yang lain, Pasal 12 Charter of the IMT secara eksplisit menetapkan bahwa:

The Tribunal shall have the right to take proceedings against a person charged with crimes set out in Article 6 of this Charter in his absence, if he has not been found or if the Tribunal, for any reason, finds it necessary, in the interests of justice, to conduct the hearing in his absence.

Pendapat lain mengemukakan bahwa pelaksanaan yurisdiksi universal in absentia dapat dilakukan dan tidak melanggar hukum internasional sepanjang due process of law diterapkan dan terdakwa diberi kesempatan untuk hadir di persidangan. Bila ternyata ia menolak untuk hadir di persidangan atau melarikan diri maka pengadilan dapat melanjutkan proses persidangan, jika mungkin. Dalam kasus ini dianggap bahwa terdakwa mengabaikan haknya untuk mendapatkan a fair trial dengan menolak hadir di pengadilan. ${ }^{34}$
Dalam praktik penerapan ATCA yang digunakan adalah proses peradilan perdata. Proses peradilan ini tidak mensyaratkan kebenaran materiil sebagaimana yang dikenal dalam hukum pidana. Dalam pelaksanaannya mengingat bahwa perbuatan yang digugat masuk kategori internasional crime, tetapi proses peradilannya menggunakan proses peradilan perdata maka hak-hak seseorang yang dituduh atau didakwa melakukan kejahatan internasional untuk mendapatkan fair trial sangat terabaikan. Hak-hak tersangka atau terdakwa untuk mendapatkan fairtrial yang di kenal dalam hukum pidana internasional yang terabaikan dalam proses persidangan di bawah ATCA adalah sebagai berikut:

1. Proses peradilan di bawah ATCA memakan waktu bertahun-tahun yang berarti melanggar prinsip peradilan cepat (expeditious trial). Hal ini terjadi karena sangat sulitnya mengumpulkan bukti dan saksi dari suatu kejahatan yang tidak memiliki keterkaitan sama sekali dengan negara forum baik menyangkut tempat maupun kewarganegaraan pelaku atau korban.

2. Seseorang yang dituduh melakukan kejahatan internasional berdasarkan ATCA tidak mendapatkan jaminan akan didampingi seorang pembela (defence councel) sebagaimana dikenal dalam hukum pidana internasional. Hal ini bertentangan dengan prinsip keseimbangan (equality of ams).

3. Hampir semua kasus yang diajukan di bawah ATCA tidak dihadiri oleh si tergugat bahkan juga kuasa hukumnya. Dengan demikian proses peradilan di bawah ATCA

\footnotetext{
${ }^{34}$ Ridarson Gallingging, op.cit., hlm. 106
} 
tidak sesuai dengan prinsip harus hadirnya. terdakwa di persidangan. (the principle that accused must be present at his trian). Meskipun dalam praktik peradilan pidana internasional ada celah -untuk melaksanakan yurisdiksi universal in absentia tetapi harus sesuai dengan due process dan pembatasan-pembatasan yang disyaratkan.

4. Dengan ketidakhadiran orang yang dituduh melakukan kejahatan internasional maupun kuasa hukumnya dalam persidangan maka kebenaran yang diperoleh dalam persidangan hanyalah kebenaran formal bukan kebenaran material sebagaimana yang dikenal dalam hukum pidana internasional. Bukti-bukti dan saksi-saksi yang diajukan pada sebagian besar kasus hanyalah bukti desas-desus berdasarkan opini, artikel surat kabar dan keterangan sepihak saja. Hal ini tidak sesuai dengan prinsip keseimbangan (equality of arms).

5. Dengan memutuskan bahwa penggugat berhak atas ganti rugi meskipun kebenaran yang diperoleh hanyalah kebenaran formal maka otomatis pengadilan menetapkan bahwa tergugat bersalah melakukan pelanggaran international crime, yang merupakan musuh seluruh umat manusia. Hal ini juga bertentangan dengan prinsip presumption of innocence yang dikenal dalam hukum pidana internasional, bilamana bukti-bukti yang diajukan tidak meyakinkan maka tuduhan harus ditolak. Proses peradilan harus dihentikan baik atas permintaan terdakwa maupun pengadilan itu sendiri. Terlepas dari pelanggaran terhadap prinsip-prinsip hukum pidana internasional, hampir semua kasus ATCA yang memutus bahwa penggugat berhak atas ganti rugi tidak dapat dilaksanakan karena tergugat tidak memiliki-aset di wilayah negara forum atau sudah memindahkan aset-aset tersebut ke luar dari wilayah negara forum. Dengan demikian sebenarnya melalui proses peradilan ATCA di satu sisi tujuan korban mendapatkan ganti rugi tidak tercapai dan di sisi lain hak-hak pihak yang dituduh melakukan international crime untuk mendapatkan fair trial terabaikan. Akan berbeda hasilnya bila proses persidangan dilakukan dalam proses peradilan pidana baik di lingkup pengadilan nasional maupun internasional. Melalui proses peradilan pidana hak-hak korban maupun terdakwa akan lebih terlindungi.

\section{Simpulan}

ATCA merupakan aturan hukum nasional Amerika yang mengatur mengenai hak WNA untuk mengajukan gugatan secara perdata di depan pengadilan pengadilan Amerika untuk mendapatkan ganti rugi atas pelanggaran $\mathrm{HI}$ terhadap dirinya. Jenis pelanggaran HI yang masuk yurisdiksi ATCA adalah kejahatankejahatan yang dalam $\mathrm{HI}$ dipandang sangat serius dan masuk kategori international crime, dimana terhadap jenis-jenis kejahatan ini berlaku yurisdiksi universal yang dipandang berada di bawah yurisdiksi ATCA adalah pelanggaran berat HAM (gross violances of human right) seperti torture, summary eecution, genocide, war crimes, disappearance, prolonged arbitrary detention, slave labor, and cruel, inhuman or degrading punishement Sebaliknya pengadilan menolak untuk mengakui perkara-perkara seperti nasionalisasi (property expropriation), support 
of armed forces and labor right of picketing. ${ }^{35}$ cultural genocide, environmental abuses, a bridgement of freedom of speech, price fixing, ordinary torts such as fraud, breach of fiduciary duty, and misappropriation of funds. Berbeda dengan yurisdiksi Universal dalam HI, ATCA melakukan pembatasan-pembatasan yurisdiksi dengan menerapkan beberapa doktrin seperti doktrin minimum contact, forum non convenience, political question, international commity juga act of state doctrine.

ATCA menggunakan proses peradilan perdata untuk international crime dimana pelakunya dianggap sebagai enemy of all nations. Banyak kelemahan yang ditemukan dalam proses peradilan ini. Hampir semua proses pengadilan tidak dihadiri tergugat maupun kuasa hukumnya sehingga tuduhantuduhan yang ditujukan pada tergugat, buktibukti dan saksi-saksi yang diajukan semuanya hanya berasal pihak penggugat saja. Hak-hak pihak yang dituduh melakukan international crime untuk mendapatkan fair trial dalam suatu proses peradilan perdata sangat terabaikan. Beberapa prinsip dalam hukum pidana internasional seperti presumption of innocence, expeditious trial, equity of arms, juga harus hadirnya terdakwa dalam persidangan sangat terabaikan. Sistem Peradilan pidana internasional sebenarnya sangat memberikan peluang pada korban untuk menuntut ganti rugi setelah terdakwa dinyatakan terbukti bersalah. Tanpa hadirnya tergugat di wilayah Amerika, juga tanpa ada aset-aset milik tergugat di Amerika maka putusan-putusan di bawah ATCA yang memberikan ganti rugi pada penggugat seolah tanpa arti. Diantara sekian banyak putusan hanya dalam 1 perkara saja ganti rugi terbayarkan pada penggugat . Itupun hanya sebagian kecil dari yang seharusnya dibayar oleh tergugat. Hal ini terjadi karena adanya prinsip par im parem non habet imperium yang dikenal dalam $\mathrm{HI}$. Negara berdaulat yang satu tidak tunduk pada negara berdaulat lainnya, termasuk dalam hal putusan pengadilannya. Dengan demikian pada prinsipnya putusan pengadilan Amerika hanya akan dapat dilaksanakan di wilayah Amerika saja, tidak di wilayah negara lain.

\section{Daftar Pustaka}

Akehurst, Michael, A Modem Introduction to International Law, George Allen and Unwin (Publisher) Ltd, Fourth edition, 1982.

Antonio Cassese, International Criminal Law, Oxford University Press, 2003

Alina Kaczorowska, Textbook :Public International Law, Old Balley Press, London. 2002

Dixon, Martin, Textbook on International Law, fourt edition, Blackctone Press Limited, London, United Kingdom, 2000

John O'Brien, International Law, Cavendish Publishing Limited, Great Britain, 2001

I Wayan Parthiana, Pengantar Hukum Internasional, Mandar Maju, 1990, Bandung

Mochtar Kusumaatmadja, Pengantar Hukum Internasional, Buku I Bagian Umum, Binacpta, Jakarta, catakan keempat, 1982

Purnadi Purbacaraka dan Agus Brotosusilo, 1989, Sendi-Sendi HukumPerdata Internaisonal Suatu Orientasi, Jakarta,

${ }^{35}$ Lisa Lambert, op.cit., hlm. 120 


\section{C.V Rajawali}

Alex Phelan," "The Alien Tort Claims Act:Successes and Limitations", Bhopal, Monday, January 23, 2006

Amnesty International, "UNIVERSAL JURIS-

- $\quad$ DICTION:14 Principles on the Effective Exercise of Universal Jurisdiction ", 1 Mei 1999,

Anne Marie Burley," The Alien Tort Statute and

- The Judiciary Act of 1789 : A Badge of Honor", dalam American Journal of Intermtaional Law, Vol. 83, No. 3, Jul., 1989, Charles F."Hollis," Perpetual Mistrial: The Impropriety of Transnational Human - - Rights Litigation in United States Courts "http://www.scu.edu/scjil/archive/ v1_HollisArticle, akses 6 Juni 2005

"Corporate Liability for Violations of International Human Rights Law," Dalam Harvard Law Review, 114 Harv. L. Rev. 2025 , May, 2001

Daphne Eviatar, "Judgment Day ; Will an Obscure law bring down the global economy?," 28 Desember 2003, unw.boston.com/globe diakses Pebruari 2005

Donald J Kochan, "Aspirin for a major Headache:Scaling back Relief Under the Alein Tort Claim Act",Federal Social Organisation joumal, Winter 2000

Henry Kissinger, "The Pitfalls of Universal Jurisdiction", 2001, www.thirdhor/ dtrawler.com/Kissinger/Pitfalls. Univ.Jurss.Kis.htm, diakses Maret 2005 Jan Wouters, "Leen De Smet \& Cedrick Ryngaert, "Tort Claim Against Multinational Companies for Foreign Violations Committed Abroad:Lesson from the Alien Tort Claim Act?"," Working Paper No 46-November 2003, Institute for In- ternational Law, Leuven University

$\mathrm{K}$ Randall, Federal Jurisdiction over international claims; Inquiries into the Alien Tort Statute", 18 New York University Jounal of International Law and Politics, 1985 Jennifer Green and Beth Stephens, "An Activist Guide: Bringing International Human Rights Claims in United States Courts", Center for Constitutional Rights, www.ccr.ny.org/v2/ilegal/dues/activist\%20 guide.pdf,akses 2 Maret 2005

Kevin R Gray, Case Cocerning the Arrest Warrant of 11 April 2000 (Democratic Republic of the Congo v Belgium ), dalam European Journal of International Law. Legal-explanation.com, "legal definition"

Lucien J Dhooge, "The Alien Tort Claims Act and the Modern Transnational Entreprise Deconstructing the Mythology of Judicial Activism," dalam Georgetown Journal of International Law, Washington, 2003, Vol.35.

"Plain Responses to Attacts on The Alien Tort Claims Act (ATCA)", Department of Policy and Business Practices, International Chamber of Commerce, December 2002, http:// www.iccwbo.org

Randall, "Federal Jurisdiction over international claims; Inquiries into the Alien Tort Statute", 18 New York University Jounal of Intrenational Law and Politics, 1985

Ridarson Galingging "Universal Jurisdiction in absentia ;Congo v Belgium, ICJ, Feb.14, 2002," dalam Jurnal Hukum Internasional, Vol I No 2, Agustus 2002, Bagian Hukum Internasional, FH Universitas Padjadjaran, Bandung

The European Commission's Amicus Curiae Brief in The Alvarez-Machain Case Tikkuna A.S.Gottschalk, "The Real Politil of 
Sefriani. Penerapan Yurisdiksi Alien Tort Claim Act ...

Empire, dalam Joumal of Transnational Law. and Policy, Vol 13/1, 2005

T Niles, "The very long arm of American Law", dalam Financial Times, 5 November 2002, juga "D Griswold, "Abuse of $18^{\text {th }}$ century law threatens U.S Economic and Security Interest, 5 Januari 2003 ; tersedia di http/wwww.cato.org/dailys/0125-03.html, diakses 2 Maret 2005

The Alien Claims Act Undèr Attact", introduction remark by Mark A Drumbl, dalam American Society of International Law, Proceedings of Annual Meeting, Washington, 2004

Tien Saefulah, "Hubungan antara Yurisdiksi Universal Dengan Kewajiban Negara Berdasarkan Prinsip Aut Dedere Aut $\therefore$ Judicare Dalam Tindak Pidana Penerbangan dan Implementasinya di indonesia" dalam Jurnal Hukum

- Internasional UNPAD, Bagian Hukum

$\therefore$ Internasional, FH Universitas . Padjadjaran, Bandung, Vol I//2002

Tom McNamara Davis Graham \& Stubbs LLP Plaintiff's Diplomacy: Are There AnyLimits on American Supercourts? October 2, 2001

USA Engage, "The Alien Tort Provision Corecting the Abuse of an Early Federalist Statute", diakses 2 Maret 2005

Williām Glaberrson, "US Court become arbjters of Global :Rights and Wrongs", dalam harian New York Times, 21 Juni 2001 . 